\title{
Studies on Tinidazole Delivery from Nano-sized Minicells Originated from Leuconostoc mesenteroides
}

\author{
L. VU, D. NGUYEN ${ }^{1}$ AND T. H. K. NGUYEN*
}

School of Biotechnology, Department of Biotechnology, International University, Vietnam National University, Ho Chi Minh City, Vietnam, ${ }^{1}$ Faculty of Natural Sciences, Thu Dau Mot University, Vietnam

Vu et al.: Improvement of Absorption of Tinidazole by Nano-sized Minicells

\begin{abstract}
This study reported the ability of Leuconostoc mesenteroides VTCC B-871 to produce nano-sized minicells for the delivery of tinidazole to improve permeation through mice intestinal membrane. Using scanning electron microscope and transmission electron microscope, morphology of minicells while loading the drug was observed. Minicells did not change spherical shape and size $(400 \mathrm{~nm})$ over the time kept in buffered saline gelatin containing tinidazole. Based on Box-Behnken design, the optimal conditions were selected for actual encapsulation. Minicells could encapsulate tinidazole approximately to $90 \%$ as determined by high performance liquid chromatographic analysis. Maximum concentration of tinidazole released from minicells was $70 \%$ at pH 3.4 and $55 \%$ at pH 7.2, respectively. Absorption of tinidazole from minicells was quantified in mice. Tinidazole could be absorbed faster from the minicells than tinidazole alone in fed mice upon oral administration. The study demonstrated that the absorption of water-insoluble tinidazole with food could be improved by Leuconostoc minicells.
\end{abstract}

Key words: Tinidazole, Box-Behnken design, drug absorption in fed mice, drug release, Leuconostoc mesenteroides, minicells

Currently, developing a novel type of drug delivery is a very important goal in pharmaceutical research, especially nanoparticle drug delivery. A drug can be packaged, dispersed or encapsulated as a nanoparticle, which acts as a drug delivery system for directing the drug to a specific target by recognizing specific ligands on target surface leading to increased penetration and efficacy. Manipulation of drug half-life, circulation time and bioavailability is possible through changing the size and surface characteristics of the nanoparticle ${ }^{[1]}$. It is worth noting that these manipulations not only improve drug absorption and therapeutic efficacy due to target specificity but also reduce dosing interval leading to decreased toxicity.

Nanoparticles can be a nanopowder, nanoclusters or nanocrystals ${ }^{[2]}$. For pharmaceutical technology, nanoparticles used as drug delivery are defined as submicron particles whose range is less than $1 \mu \mathrm{m}$. The materials are different varieties including polymers, lipids (liposomes), magnetic, even inorganic or metallic compounds (iron, silica) and bacterial nanoparticles or minicells. Normally, drug releases from nanoparticles is by diffusion, erosion, swelling, and degradation

*Address for correspondence E-mail: nhktu@hcmiu.edu.vn

March-April 2019 after entering the body. However, there has been limited success due to several reasons that included, low drug loading in cell-carrier, untimely drug release instead of continuous release over time and limited drug administration because of its characteristics. As all of these problems had been reported in many nanoparticles, e.g. liposomes, micelles, nanospheres and nanofibers ${ }^{[1]}$, finding an ideal drug delivery system with an optimal size, shape and surface characteristics including the specific target binding size is still a challenge for the scientists.

Minicell is described as a type of abnormal division in bacteria, which came from mutation or stress environment ${ }^{[3]}$, resulting in a small spherical bacterium whose diameter is less than $1 \mu \mathrm{m}$. Scientists suggested that this was a new term for nanocells, due to the fact that it has its diameter in the range of a nanometer.

This is an open access article distributed under the terms of the Creative Commons Attribution-NonCommercial-ShareAlike 3.0 License, which allows others to remix, tweak, and build upon the work non-commercially, as long as the author is credited and the new creations are licensed under the identical terms

Accepted 20 January 2019

Revised 12 June 2018

Received 20 February 2017

Indian J Pharm Sci 2019;81(2):234-240 
Even though the minicell has a disrupted cell cycle and contains no chromosomal DNA, it still retains most components from the parent cell including lipopolysaccharides, cell wall, normal envelop structures, transport system and the ability to transcribe or translate the genes of recombinant plasmid if the plasmid is present in minicells. Therefore, minicells could be a good carrier candidate. At present, there are some strains of bacteria reported to possibly induce a form of minicel1 ${ }^{[4,5]}$ such as Bacillus subtilis ${ }^{[6]}$, Salmonella typhimurium ${ }^{[7]}$, Haemophilus influenza ${ }^{[8]}$, Shigella flexneri ${ }^{[9]}$, Pseudomonas aeruginosa ${ }^{[10]}$ and Listeria monocytogenes ${ }^{[11]}$. Recently, using intact bacterial minicells for drug delivery to distribute the drug into a specific target in both in vivo and in vitro conditions is being regarded as a novel delivery $\operatorname{approach}^{[4,5]}$.

Probiotics are living microorganisms, which cause health benefits to the host ${ }^{[12]}$. Some bacterial strains such as Lactobacillus, Leuconostoc, Bifidobacterium are listed among probiotics. Moreover, many researchers have indicated that the probiotic effect is strainspecific, which means that the bacteria only express the effect in specific cases triggered by their exposure to particular characteristics such as resistance to gastric acid and bile or the ability to colonize in mucosa and antimicrobial activity ${ }^{[13]}$.

The genus Leuconostoc belongs to the family of Leuconostocaceae. Leuconostocs are closely related to Fructobacillus, Weissella and Oenococcus. Together, they are commonly known as the Leuconostoc group of lactic acid bacteria (LAB). Besides improving biological functions of the host, the LAB group also plays an important role in treating tumors in immune compromised subjects. According to Bergey's manual of systematic bacteriology, Leuconostoc is a Grampositive bacterium that has small cells and its regular, generally ovoid cocci are linked to form short chains. The other characteristics include non-motility, no spore formation but acid-loving. These bacteria would not uncommonly cause a disease to human and also affected on the immune system by acting the immune cells via different mechanism signals ${ }^{[14]}$. Based on these properties, Leuconostoc mesenteroides was chosen to develop a drug delivery system ${ }^{[15]}$.

Tinidazole, which mainly contains 5-nitroimidazoles, is an analogue structure of metronidazole, a popular antiprotozoal agent with effectiveness and acceptable tolerability. In 1991, high level of metronidazole resistance was reported as 1 in over 2000-3000 cases, especially in vaginal trichomoniasis. Tinidazole is poorly dissolved in water $\left(1.99 \times 10^{-4} \mathrm{mg} / \mathrm{l}\right)$. Administration of tinidazole with food reduce $10 \%$ of $\mathrm{C}_{\max }{ }^{[16]}$. These problems led to a need for the development of tinidazole formulation for higher effects in case of food presence.

Therefore, there is a need to develop improved tinidazole formulations. In this study, tinidazole is packaged in a drug delivery system. In order to find out the best condition for packaging study or drug encapsultation efficiency, Box-Behnken experimental design ${ }^{[17]}$ was used for analyzing multivariate experiments ${ }^{[18]}$. Leuconostoc mesenteroides minicells were assessed for ability to encapsulate and release tinidazole through in vivo evaluation of permeation across small intestine in combination with food. This is the first in vivo study of Leuconostoc mesenteroides on insoluble tinidazole delivery in the combination with food.

\section{MATERIALS AND METHODS}

Leuconostoc mesenteroides VTCC-B-871 was purchased from Vietnam type culture collection (Vietnam). Lactobacilli MRS broth, D-glucose, acetonitrile, gelatin, formaldehyde and sodium chloride were from Merck (Germany). Standard tinidazole was obtained from Institute for Drug Quality Control, Ministry of Health (Vietnam). $0.45 \mu \mathrm{m}$ filter membrane (Sigma, USA), dialysis tube (Sigma, USA), centrifuge (Kubota, Japan), optical microscope (Labomed, USA), scanning electron microscope (Hitachi S-4800, Japan), transmission electron microscope (Jeol JEM-1400), microplate reader (Bioteck, UsA), high performance liquid chromatography (HPLC) system including C18-column and DAD-detector (Shimazu, Japan), pH meter (Schott, Germany) were used in the study.

\section{Leuconostoc minicell preparation:}

Leuconostoc bacterium was incubated in modified Lactobacilli MRS broth with $20 \%$ D-glucose for $48 \mathrm{~h}$ at room temperature. The culture was collected and checked to ensure minicell formation before isolation according to a procedure previously reported ${ }^{[18]}$.

\section{Minicell stability test:}

First, the minicell fraction was separated with parent bacterial cells and cell debris for further purification. The culture was centrifuged at $3500 \mathrm{~g}$ in $20 \mathrm{~min}$ to remove the large cells. After the supernatant had been collected, it was filtered through a $0.45 \mu \mathrm{m}$ filter 
membrane twice to completely separate minicells from cell debris and parent cells. Then, the collected supernatant was centrifuged at $15000 \mathrm{~g}$ up to $20 \mathrm{~min}$. The collected pellets were minicells. Minicells were then re-suspended in $1 \mathrm{X}$ buffered saline gelatin (BSG) solution and kept for later use.

\section{Microscopic test:}

The isolated minicells were observed by light microscope at $100 \mathrm{X}$ magnification for counting the number of minicells and examining their morphology. The number of minicells was calculated using the following Eqn., the density of obtained minicells $($ cell $/ \mathrm{ml})=($ number of cells $\times 10000) /$ number of squares.

\section{Scanning electron microscopy (SEM) and} transmission electron microscopy (TEM):

In order to determine the size of minicells, SEM was used. Before scanning, minicells were mixed with $4 \%$ formaldehyde in phosphate buffered saline (PBS) solution and incubated overnight at room temperature. After that, minicells were collected and washed with PBS solution to remove formaldehyde completely. Minicells were dehydrated respectively with 30, 50, 70, 80, 90 and $100 \%$ alcohol. Each dehydration step took $10 \mathrm{~min}$ for incubation. Minicells after encapsulating tinidazole were observed under TEM.

\section{Designing the optimal conditions for packaging minicells with tinidazole:}

Optimization was based on the Box-Behnken experimental design. Tables 1 and 2 showed the design for tinidazole incubated minicells in different time. All 15 cases were carried out for setting up the Box-Behnken program. The system involved 3 independent factors, volume of tinidazole (X1), tinidazole concentration (X2), time of incubation (X3). The mathematical relationship between these factors was approximately quantified using the quadratic Eqn., $\mathrm{Y}=\mathrm{C}_{0}+\mathrm{C}_{1} \mathrm{X}_{1}+\mathrm{C}_{2} \mathrm{X}_{2}$ $+\mathrm{C}_{3} \mathrm{X}_{3}+\mathrm{C}_{12} \mathrm{X}_{1} \mathrm{X}_{2}+\mathrm{C}_{13} \mathrm{X}_{1} \mathrm{X}_{3}+\mathrm{C}_{23} \mathrm{X}_{2} \mathrm{X}_{3}+\mathrm{C}_{11} \mathrm{X}_{1}{ }^{2}+\mathrm{C}_{22} \mathrm{X}_{2}^{2}+\mathrm{C}$ ${ }_{33} \mathrm{X}_{3}^{2}$, where $\mathrm{Y}$ is the predicted yield, $\mathrm{C}_{0}$ is the constant response; $\mathrm{C}_{1}, \mathrm{C}_{2}$ and $\mathrm{C}_{3}$ are the linear coefficients, $\mathrm{C}_{12}$,

TABLE 1: THE LEVELS OF VARIABLES CHOSEN FOR THE TRIALS

\begin{tabular}{lcc}
\hline Volume of minicells $(\mu \mathrm{l})$ & Tinidazole $(\mathrm{mg} / \mathrm{ml})$ & Time $(\mathrm{h})$ \\
\hline $10(-1)$ & $0.1(-1)$ & $4(-1)$ \\
$55(0)$ & $0.5(0)$ & $10(0)$ \\
$100(1)$ & $0.9(1)$ & $16(1)$ \\
\hline
\end{tabular}

TABLE 2: EXPERIMENTAL AND THEORETICALLY PREDICTED VALUES FOR CONCENTRATION OF TINIDAZOLE-MINICELLS

\begin{tabular}{lcc}
\hline Experimental no. & $\begin{array}{c}\text { Actual value } \\
(\mathrm{mg} / \mathrm{ml})\end{array}$ & $\begin{array}{c}\text { Predicted value } \\
(\mathrm{mg} / \mathrm{ml})\end{array}$ \\
\hline 1 & 0.0992 & 0.0989 \\
2 & 0.8996 & 0.8997 \\
3 & 0.0998 & 0.0996 \\
4 & 0.8994 & 0.8997 \\
5 & 0.4999 & 0.4999 \\
6 & 0.4995 & 0.4995 \\
7 & 0.4999 & 0.4999 \\
8 & 0.4999 & 0.4999 \\
9 & 0.0996 & 0.0997 \\
10 & 0.0996 & 0.0999 \\
11 & 0.8998 & 0.8996 \\
12 & 0.8994 & 0.8993 \\
13 & 0.4987 & 0.4988 \\
14 & 0.4987 & 0.4989 \\
15 & 0.4987 & 0.4985 \\
\hline
\end{tabular}

$\mathrm{C}_{13}$ and $\mathrm{C}_{23}$ are the cross product coefficients and $\mathrm{C}_{11}$, $\mathrm{C}_{22}$ and $\mathrm{C}_{33}$ are the quadratic coefficients.

\section{Drug encapsulation efficiency (EE):}

Based on the design, tinidazole and Leuconostoc minicells were combined in different conditions. The mixtures were collected by centrifugation at $15000 \mathrm{~g}$ within $30 \mathrm{~min}$ at $4^{\circ}$. The supernatant was used to quantify remaining tinidazole based on the optical density measurement. Then, tinidazole concentration in minicells was determined by subtracting the concentration of the remaining tinidazole from the initial tinidazole concentration. EE was calculated using the Eqn., encapsulation efficiency $=($ drug concentration in minicells $\times 100$ )/total drug concentration.

\section{In vitro dissolution test:}

Dialysis tube was employed for nanoparticles dissolution test ${ }^{[19]}$. The amount of released drug was measured as absorbance using a multi-mode microplate reader. Dissolution of tinidazole loaded in minicells was studied in simulated gastric juice ( $\mathrm{pH}$ 3.4) and plasma like fluid $(\mathrm{pH}$ 7.2) during $24 \mathrm{~h}$. Supernatants were collected at $0.5,1,1.5,2$, $2.5,3,4,5,6,12$ and $24 \mathrm{~h}$. The drug release levels were measured and analyzed the peak area of each drug on HPLC.

\section{Absorption of tinidazole-minicells:}

Before mice were administered with tinidazoleminicells and tinidazole (400 $\mu \mathrm{g}$, a single $50 \mathrm{mg} /$ $\mathrm{kg}$ dose), mice were fed normally and observed for 
1 mo. After this period, mice were orally administered with tinidazole-minicells or tinidazole in fed state. Blood samples were withdrawn every $1 \mathrm{~h}$, and analyzed for the amount of tinidazole.

\section{Bioanalysis of tinidazole in blood:}

Mice were restrained to sample blood from the tail. Blood was then mixed with acetone and vortexed at $2000 \mathrm{~g}$. Precipitated blood cells was collected by a $5000 \mathrm{~g}$ centrifugation step for $20 \mathrm{~min}$ at $4^{\circ}$. The supernatant containing tinidazole was separated. Tinidazole concentration was then measured using HPLC.

\section{HPLC:}

The mobile phase contained acetonitrile, methanol and phosphate buffer ${ }^{[20]}$. The flow rate was at $1 \mathrm{ml} /$ $\min$ on a $\mathrm{C} 18$ column. The UV/Vis detector was set at $320 \mathrm{~nm}$. The limit of detection was $0.05 \mu \mathrm{g} / \mathrm{ml}$.

\section{Antiprotozoal activity:}

In order to confirm tinidazole in serum, sera collected in 1, 2, 3, 4 and $5 \mathrm{~h}$ were used to test on Trichomonas. The method was agar dilution test. Tinidazole was dissolved in dimethyl sulfoxide and diluted in sterile distilled water and then added in the semisolid agar for yeast mold (Cat No.1194, Conda, Spain). One inoculum was prepared with turbidity equaling to $0.5 \mathrm{McF}$ arland standard. One microlitre of the inoculum suspension was dropped into medium with or without tinidazole. All cultures were incubated at $35^{\circ}$ until stable growth in medium without tinidazole. Colony count was done in medium with or without containing tinidazole. The percent inhibition by tinidazole was calculated based on the ratio of survival colonies grown in medium with or without containing tinidazole.

\section{Data analysis:}

The results in triplicate for all experiments were expressed as mean \pm standard deviation (SD) and then analyzed using one tailed t-test and two tailed t-test for paired comparison of means. The statically significant differences were considered with $\mathrm{p}<0.05$.

\section{RESULTS AND DISCUSSIONS}

The Leuconostoc minicell diameter was less than $400 \mathrm{~nm}$ even kept in BSG solution for $1 \mathrm{mo}$ as well as packaged with tinidazole. Fig. 1 shows the representatives of minicells in nano size after incubation when they were observed under both SEM and TEM. From these results, it was observed that minicells were stable for a long time and did not aggregate, suggesting that these could be used as a vehicle for drug delivery.

According to different concentration levels of tinidazole packaged with minicells (tinidazoleminicells), which was generated with different volumes of minicells, tinidazole concentrations and time of incubations, the regression Eqn. was derived $^{[21]}$. $\mathrm{Y}=0.4987+0.0001 \mathrm{X}_{1}+0.4000 \mathrm{X}_{2}-0.0001 \mathrm{X}_{3}-$ $0.0002 \mathrm{X}_{1} \mathrm{X}_{2}+0.0001 \mathrm{X}_{1} \mathrm{X}_{3}-0.0001 \mathrm{X}_{2} \mathrm{X}_{3}+0.0005 \mathrm{X}_{1}^{2+}$ $0.0003 \mathrm{X}_{2}^{2}+0.0006 \mathrm{X}_{3}^{2}$, where, $\mathrm{Y}$ is the concentration of tinidazole-minicells. The quadratic regression was significant at the level of $95 \%$. The conditions for packaging tinidazole with minicells were based on this Eqn. From this conditioned matrix, predicted and experimental results of minicells in packaging tinidazole were summarized in Table 2.

High level of fitness between the predicted and the actual value of response Y showed that the model was valid for designing optimal conditions for packaging minicells with tinidazole rapidly. From Tables 2 and 3, approximately $99 \%$ EE could be obtained under conditions 2, 4, 11, 12. The correlations between time of incubation, volume of minicells, tinidazole concentration with tinidazole-minicell concentration were shown in figs. 2 and 3 . To understand the location of tinidazole in minicells, SEM analysis was used (fig. 1). Especially, the morphology and the size of minicells were like the minicells before drug packing.

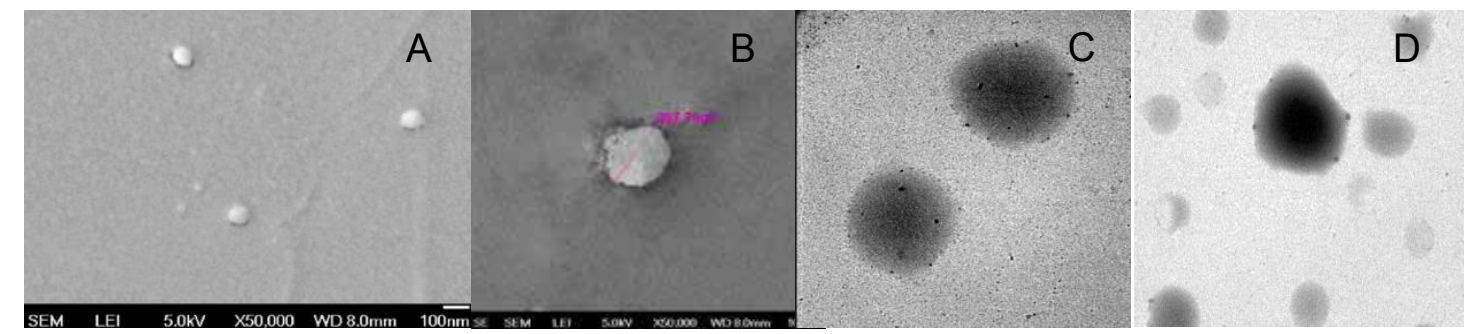

Fig. 1: The morphology of minicell representatives (A) and (B) SEM analysis; (C) and (D) TEM analysis 
TABLE 3: THE MATRIX OF VARIABLES CHOSEN FOR THE TRIALS

\begin{tabular}{lccc}
\hline Trial & $\begin{array}{c}\text { Volume of } \\
\text { minicells }(\boldsymbol{\mu l})\end{array}$ & $\begin{array}{c}\text { Tinidazole } \\
(\mathrm{mg} / \mathrm{ml})\end{array}$ & Time $(\mathrm{h})$ \\
\hline 1 & 10 & 0.1 & 10 \\
2 & 10 & 0.9 & 10 \\
3 & 100 & 0.1 & 10 \\
4 & 100 & 0.9 & 10 \\
5 & 10 & 0.5 & 4 \\
6 & 10 & 0.5 & 16 \\
7 & 100 & 0.5 & 4 \\
8 & 100 & 0.5 & 16 \\
9 & 55 & 0.1 & 4 \\
10 & 55 & 0.1 & 16 \\
11 & 55 & 0.9 & 4 \\
12 & 55 & 0.9 & 16 \\
13 & 55 & 0.5 & 10 \\
14 & 55 & 0.5 & 10 \\
15 & 55 & 0.5 & 10 \\
\hline
\end{tabular}

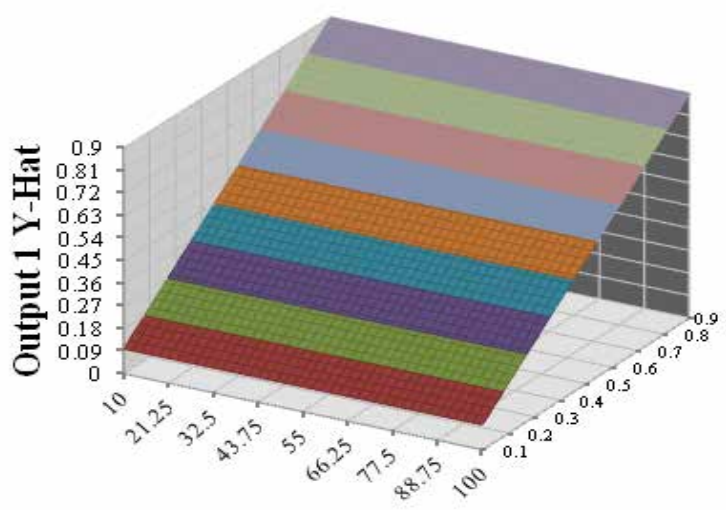

Minicell (ml) (A)

Fig. 2: Contour plot of tinidazole-minicells, volume of minicells and tinidazole concentration

Contour plot representing concentration of tinidazole-minicell versus volume of minicells and tinidazole concentration. $\square$ 0.81$0.9 ;=0.72-0.81 ; \approx 0.63-0.72 ;=0.54-0.63 ; \square 0.845-0.54 ;=0.36-$ $0.45 ; \quad$ 0.27-0.36; $\approx$ 0.18-0.27; $\approx$ 0.09-0.18; $\approx 0.0-09$

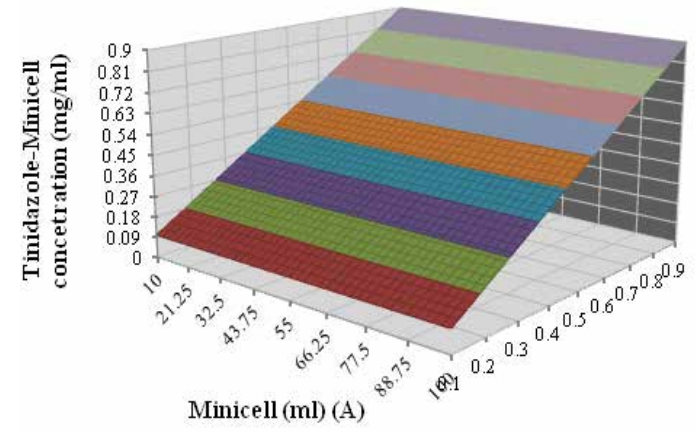

Fig. 3: Contour plot of tinidazole-minicells, time of incubation and tinidazole concentration

Contour plot representing concentration of tinidazole-minicell versus time of incubation and tinidazole concentration $\square$ 0.81$0.9 ;=0.72-0.81 ; \approx 0.63-0.72 ; \approx 0.54-0.63 ; \approx 0.845-0.54 ;=0.36-$ $0.45 ; \quad 0.27-0.36 ;=0.18-0.27 ; \square 0.09-0.18 ; \square 0.0-0$
Tinidazole must be released from minicells under suitable $\mathrm{pH}$ conditions to show bioavailability when minicells were administered orally. Therefore, the media at $\mathrm{pH} 3.4$ and 7.2 were used in the dissolution test (fig. 4). The maximal concentration of tinidazole released from minicells was $70 \%$ at $\mathrm{pH} 3.4$ and $55 \%$ at $\mathrm{pH} 7.2$ after $24 \mathrm{~h}$, respectively. The release pattern indicated that the formulation was able to prevent drug leakage and loss during the packaging process. Besides, there were significant differences in release of tinidazole from tinidazole-loaded minicells between pH 3.4 and 7.4 (fig. 4).

During HPLC analysis, the retention time of the peak appeared in the chromatogram of blood sample (3.5265 min) was similar to that of the standard tinidazole (3.5395 $\mathrm{min})$, which indicated that tinidazole was absorbed into blood (fig. 5). Moreover, tinidazole-minicells could be absorbed into blood to give higher tinidazole levels than from tinidazole alone in fed mice. The concentration of tinidazole in serum was determined every $1 \mathrm{~h}$ during the first $5 \mathrm{~h}$ (Table 4). After $2 \mathrm{~h}$ of absorption, tinidazole-minicells in serum was $8.1567 \pm 2.4007 \mu \mathrm{g}$ while tinidazole in blood was $1.3133 \pm 0.9059 \mu \mathrm{g}$. Tinidazole-minicells gave tinidazole absorption showed the highest maximal concentration after $2 \mathrm{~h}$ absorption in fed mice. Tinidazole-minicells could be absorbed faster to give 8 times higher plasma concentration than tinidazole alone in fed mice. After $5 \mathrm{~h}$, tinidazole concentration in both cases reduced (fig. 5). However, the tinidazole concentration from minicell formulation always gave a higher amount than from tinidazole alone. By testing the activity on Trichomonas, isolated serum was found to inhibit Trichomonas (Table 5), which suggested that tinidazole was present in the serum. The study also pointed that minicells could not be digested by immunological system.

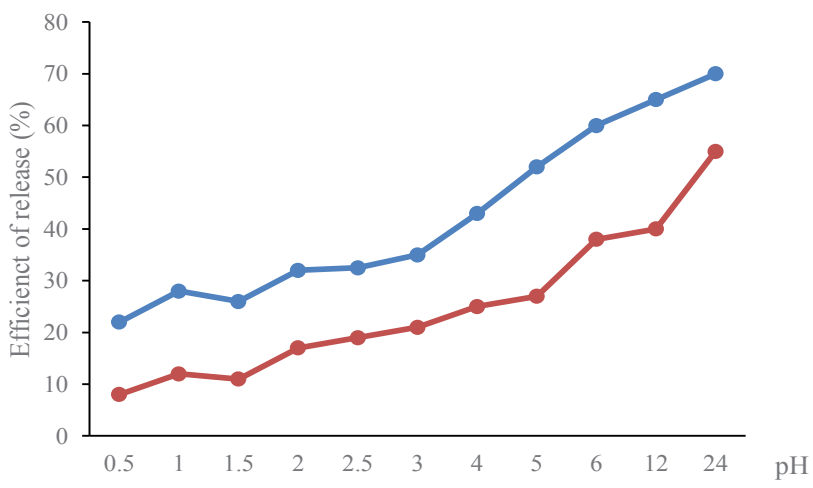

Fig. 4: Tinidazole releasing in different $\mathrm{pH}$ - $-\mathrm{pH} 3.4$; $-\bullet-\mathrm{pH} 7.2$ 
TABLE 4: CONCENTRATION OF TINIDAZOLE AND TINIDAZOLE-MINICELLS IN SERUM

\begin{tabular}{lcccccc}
\hline \multirow{2}{*}{ Drugs } & \multicolumn{5}{c}{ Concentration $\mathbf{( m g / m l )}$} \\
\cline { 2 - 7 } & $\mathbf{0 ~ h}$ & $\mathbf{1 h}$ & $\mathbf{2 h}$ & $\mathbf{3 h}$ & $\mathbf{4 h}$ & $\mathbf{5} \mathbf{h}$ \\
\hline Tinidazole & 0 & $0.29 \pm 0.59$ & $1.3133 \pm 0.9$ & $1.09 \pm 0.85$ & $0.54 \pm 0.73$ & $0.32 \pm 0.27$ \\
Tinidazole-minicells & 0 & $2.31 \pm 0.63$ & $8.1567 \pm 2.4$ & $7.19 \pm 1.2$ & $6.39 \pm 0.48$ & $3.17 \pm 0.94$ \\
\hline
\end{tabular}

Results are expressed as mean \pm standard deviation (SD)

TABLE 5: ANTITRICHOMONAS ABILITIES OF TINIDAZOLE AND TINIDAZOLE-MINICELLS COLLECTED FROM SERUM

\begin{tabular}{lcccccc}
\hline Drugs & \multicolumn{5}{c}{ Inhibition (\%) } \\
\cline { 2 - 7 } & $\mathbf{0 ~ h}$ & $\mathbf{1 ~ h}$ & $\mathbf{2 h}$ & $\mathbf{3 h}$ & $\mathbf{4 h}$ & $\mathbf{5} \mathbf{h}$ \\
\hline Tinidazole & $0 \%$ & $1 \pm 0.5$ & $6 \pm 0.41$ & $6 \pm 0.28$ & $3 \pm 0.2$ & $1 \pm 0.64$ \\
Tinidazole- minicells & $0 \%$ & $10 \pm 1.3$ & $40 \pm 1.12$ & $35 \pm 0.56$ & $30 \pm 0.37$ & $17 \pm 0.09$ \\
\hline
\end{tabular}

Results are expressed as mean \pm standard deviation (SD)

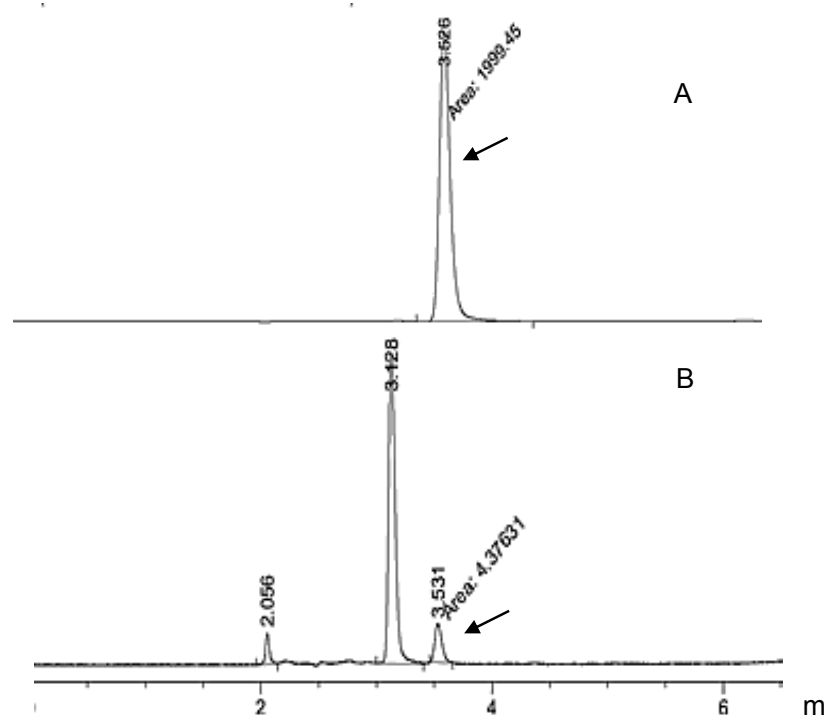

Fig. 5: HPLC of standard (A) tinidazole, and (B) tinidazole in serum

In this study, the stability of Leuconostoc minicells, encapsulation, dissolution and in vivo absorption were investigated. As seen in fig. 1, Leuconostoc minicells were stable for a time because the change of the component of outer layer of bacterium due to the sugar stress when cultured in the presence different sugars $^{[22]}$. Moreover, there was connection of cell division inhibition proteins, like FtsZ and MinD with sugars, leading to cell differentiation of $\mathrm{LAB}^{[23]}$. This property is very important for development of new type of drug delivery. By using Box-Benken design for encapsulation experiment, we found out the best condition for tinidazole packaging with minicells.

In figs. 2 and 3, concentration of tinidazole-minicells showed a direct proportion to concentration of tinidazole together with time of incubation and volume of minicells. Here the maximum concentration of tinidazole in minicells was achieved experimentally when incubating $10 \mathrm{ml}$ of minicells $(0.9 \mathrm{mg} / \mathrm{ml})$ for $10 \mathrm{~h}$. In the other trials, the volume of minicells was too high while tinidazole concentration was too low and vice versa. Therefore, the encapsulation efficacy was not ideal as other conditions mentioned in Table 3. Tinidazole could be packaged and released out of minicells that probably, oxygen of nitro moiety of tinidazole interacted with the hydrogen of hydroxyl group of sugar monomers. This bond could be convertible, leading to tinidazole getting packaged in and released out of minicells. Therefore, the drug packaging time should be optimized to get high efficacy (fig. 4). The release started after $2 \mathrm{~h}$ in the $\mathrm{pH}$ media peaking at $24 \mathrm{~h}$. Tinidazole released from minicells in basic medium was slower than from acidic medium. Probably, the acidic medium could involve in hydrolysis of the bond of minicells and tinidazole.

As seen in fig. 5, tinidazole from minicells was determined in blood more highly than tinidazole used alone in fed mice. It was meant that Leuconostoc minicells had the cell structure homogenizing with intestinal tract membrane as phospholipid that tinidazole-minicells could pass easily. The study suggested that tinidazole should be delivered by Leuconostoc minicells. With this delivery system, food did not interfere the absorption of tinidazole as informed before. To sum up, Leuconostoc could be used as a drug delivery system for tinidazole when differentiating into minicells under different sugar medium. The delivery ability of these minicells seemed similar as minicells originated from mutant bacteria, like Bacillus ${ }^{[24]}$. Minicells prepared in the study were safer when there was no effect caused by genetic engineering. This study suggested an efficient drug delivery system for poorly water-soluble compounds to improve absorption in the presence of food ${ }^{[25,26]}$.

\section{Conflict of interest:}

Authors declared that there is no conflict of interest. 


\section{REFERENCES}

1. Batrakova EV, Gendelman HE, Kabanov AV. Cell-mediated drug delivery. Expert Opin Drug Deliv 2011;8:415-33.

2. Fahlman BD. Materials Chemistry. 2nd ed. Dordrecht, Netherlands: Springer Nature BV; 2011.

3. Alden M, Rogers S. Segregation of genes for nitrogen fixation into minicells of Escherichia coli. Proc Soc Exp Biol Med 1977;155(3):357-60.

4. MacDiarmid JA, Mugridge NB, Weiss JC, Phillips L, Burn AL, Paulin RP, et al. Bacterially derived $400 \mathrm{~nm}$ particles for encapsulation and cancer cell targeting of chemotheraperutics. Cancer Cell 2007;11(5):431-45.

5. MacDiarmid JA, Amaro-Mugridge NB, Weiss JM, Sedliarou I, Wetzel S, Kochar K, et al. Sequential treatment of drugresistant tumors with targeted minicells contaning siRNA or a cytotoxic drug. Nat Biotechnol 2009;27(7):643-51.

6. Reeve JN, Mendelson NH, Coyne SI, Hallock LL, Cole RM. Minicells of Bacillus subtilis. J Bacteriol 1973;114(2):860-73.

7. Sheehy RJ, Allison DP, Curtiss R 3rd. Cryptic plasmids in a minicell-producing strain of Salmonella typhimurium. J Bacteriol 1973;114(1):439-42.

8. Sedgwick B, Setlow JK, Boling ME, Allison DP. Minicell production and bacteriophage superinducibility of thymidinerequiring strains of Haemophilus influenzae. J Bacteriol 1975;123:1208-17.

9. Gemski P, Griffin DE. Isolation and characterization of minicell-producing mutants of Shigella spp. Infect Immun 1980;30(1):297-302.

10. Kokjohn TA, Miller RV. Characterization of the Pseudomonas aeruginosa rec A analog and its protein product: rec-102 is a mutant allele of the $P$. aeruginosa $\mathrm{PAO}$ recA gene. J Bacteriol 1987;169(4):1499-508.

11. Setlow JK, Boling ME, Allison DP, Beattie KL. Relationship between prophage induction and transformation in Haemophilus influenzae. J Bacteriol 1973;115(1):153-61.

12. Hickson M. Probiotics in the prevention of antibioticassociated diarrhoea and Clostridium difficile infection. Therap Adv Gastroenterol 2011;4(3):185-97.

13. Jacobsen CN, Rosenfeldt Nielsen V, Hayford AE, Moller PL, Michaelsen KF, Paerregaard A, et al. Screening of probiotic activities of forty-seven strains of Lactobacillus spp. by in vitro techniques and evaluation of the colonization ability of five selected strains in humans. Appl Environ Microbiol 1999;65(11):4949-56.
14. Garvie EI. Genus Leuconostoc. In: PHA Sneath NSM, Sharpe ME, Holt JG, editor. Bergey's manual of systematic bacteriology. Philadelphia, Pennsylvania: Lippincott Williams and Wilkins; 1986. p. 1071-5.

15. Nguyen QT, Nguyen HKT. Minicell formation of Leuconostoc Mesenteroides in pharmaceutical science. GJBAHS 2015;4:80-4.

16. Fung HB, Doan TL. Tinidazole: a nitroimidazole antiprotozoal agent. Clin Ther 2005;27(12):1859-84.

17. Box GEP, Behnken DW. Some New three level designs for the study of quantitative variables. Technometrics 1960;2:455-75.

18. Ferreira SL, Bruns RE, Ferreira HS, Matos GD, David JM, Brandao GC, et al. Box-Behnken design: an alternative for the optimization of analytical methods. Anal Chim Acta 2007;597(2):179-86.

19. Michalowski CB, Guterres SS, Dalla Costa T. Microdialysis for evaluating the entrapment and release of a lipophilic drug from nanoparticles. J Pharm Biomed Anal 2004;35:1093-100.

20. Rajnarayana K, Chaluvadi MR, Alapati VR, Mada SR, Jayasagar G, Krishna DR. Validated HPLC Method for the determination of tinidazole in human serum and its application in a clinical pharmacokinetic study. Pharmazie 2002;57(8):535-7.

21. Paim C, Führ F, Miron D, Steppe M, Schapova EE. Highly selective colorimetric method to determine gemfloxacin mesylate in the presence of a synthetic impurity. J AOAC Int 2014;97(1):94-8.

22. Nguyen T, Doan V. Effects of carbon sources on cell differentiation of Lactobacillus rhamnosus PN04 and applications. Biomed Pharmacol J 2013;6:197-203.

23. Nguyen THK, Doan VTT, Ha LD, Nguyen HN. Molecular cloning, expression of MinD gene from Lactobacillus acidophilus VTCC-B-871 and analyses to identify Lactobacillus rhamnosus PN04 from Hottuynia cordata Thunb. Indian J Microbiol 2013;53:385-90.

24. Reeve JN, Mendelson NH. Minicells of Bacillus subtilis. A unique system for transport studies. Biochim Biophys Acta 1974;352(2):298-306.

25. Kwon GS. Polymeric micelles for delivery of poorly watersoluble compounds. Crit Rev Ther Drug Carrier Syst 2003;20:357-403.

26. Provine H, Hadley S. Preliminary evaluation of a semisolid agar antifungal susceptibility test for yeasts and molds. J Clin Microbiol 2000;38:537-41. 